\title{
p53 Protein overexpression in cholangiocarcinoma arising in primary sclerosing cholangitis
}

\author{
P M Rizzi, S D Ryder, B Portmann, J K Ramage, N V Naoumov, Roger Williams
}

\begin{abstract}
The protein encoded by the p53 tumour suppressor gene plays an important part in the regulation of cell growth. Abnormalities of this gene represent one of the most common genetic changes in the development of human cancers. This study investigated the expression of p53 protein in cholangiocarcinoma arising in association with primary sclerosing cholangitis (PSC). Of the 14 patients with cholangiocarcinoma studied, 13 had underlying PSC. The expression of p53 protein was detected immunohistochemically in paraffin wax embedded liver specimens, after microwave pretreatment. The expression of p53 protein was shown in the cholangiocarcinoma tissue of 11 of $14(78.5 \%)$ patients. In five of 10 patients, the accumulation of $p 53$ protein highlighted the presence of neoplastic cells in biliary tissue separate from the main tumour. These cells were mainly located in the septal bile ducts or in the accessory glands, or both, but occasionally also in large portal areas at the periphery of nerves and lymphatics, and in one case in the mucosa of an extrahepatic bile duct. No p53 protein was detectable in liver tissue obtained at the time of transplantation in 15 patients with PSC but not cholangiocarcinoma. These results show that cholangiocarcinoma development in PSC is commonly associated with abnormalities of p53 and that these occur at a late stage in the development of the malignant process. Staining for p53 protein could represent an additional criterion for the diagnosis of cholangiocarcinoma development in patients with PSC.

(Gut 1996; 38: 265-268)
\end{abstract}

Keywords: $\mathrm{p} 53$, cholangiocarcinoma, primary sclerosing cholangitis.

Institute of Liver Studies, King's College Hospital, London P M Rizzi S D Ryder B Portmann J K Ramage N V Naoumov

Roger Williams

Correspondence to: Professor Roger Williams, Institute of Liver Studies, King's College Hospital, Denmark Hill, London SE
9RS.

Accepted for publication 28 July 1995
Inactivation of the p53 tumour suppressor gene is a frequent step in the development of human cancer. ${ }^{1}$ Two essential functions of the protein encoded by this gene are now recognised: to arrest the cell cycle in the $G_{1}$ phase, tors to repair their DNA, or to induce apoptosis, programmed cell death. ${ }^{2}$ Mutations in the p53 gene may block these normal functions and result in prolonged survival of cells carrying DNA mutations. Mutations in the gene lead to a synthesis of an abnormal p53 protein, which has a longer half life and accumulates in permitting the cells exposed to mutagenic fac- cell nuclei. The half life of this mutated protein (between four to eight hours) is longer than that of the wild type (five to 20 minutes), permitting detection by immunohistochemistry. ${ }^{3}$

Mutations of the p53 tumour suppressor gene and overexpression of $\mathrm{p} 53$ protein have been described in liver tumours originating from hepatocytes, such as hepatocellular carcinoma $^{45}$ and hepatoblastoma. ${ }^{6}$ A comparatively high incidence of p53 mutations has also been shown recently in gall bladder carcinoma. ${ }^{7}$ In addition, patients with the Li-Fraumeni syndrome, a condition with an inherited germ line mutation affecting the p53 gene, develop cholangiocarcinoma. ${ }^{8}$ Therefore, changes in the function of this gene may participate in biliary tract carcinogenesis.

Development of cholangiocarcinoma in primary sclerosing cholangitis (PSC) is common, the prevalence of the tumour varying from $7 \%$ in asymptomatic patients to $42 \%$ of necropsy series. ${ }^{9}$

In this study we have investigated the expression of $\mathrm{p} 53$ protein in cholangiocarcinoma and PSC.

\section{Methods}

Fourteen patients with cholangiocarcinoma were studied, 13 of whom had underlying PSC. Nine patients were male and five female, median age 40 years. Ten patients underwent orthotopic liver transplantation, and four partial liver resection.

Non-neoplastic biliary tissue surrounding the tumour area was available for study in the specimens examined from 10 of 14 patients. In one patient with PSC a specimen from an extrahepatic bile duct was obtained by endoscopic retrograde cholangiopancreatography (ERCP) biopsy. Liver tissue from 15 patients transplanted for PSC with no evidence of cholangiocarcinoma in the explanted liver was also studied.

The expression of p53 protein was compared with the serum biochemistry tests (albumin, bilirubin, and alkaline phosphatase), the serum tumour markers for cholangiocarcinoma (carcinoembryonic antigen and carbohydrate antigen 19-9), ${ }^{10}$ and the histological classification of cholangiocarcinoma.

Detection of $p 53$ protein expression

Cellular expression of $\mathrm{p} 53$ protein was detected in formalin fixed, paraffin wax embedded tissue specimens using the avidin-biotin-peroxidase complex method. Sections were deparaffinised, rehydrated through graded alcohols, and the endogenous peroxidase activity was blocked 


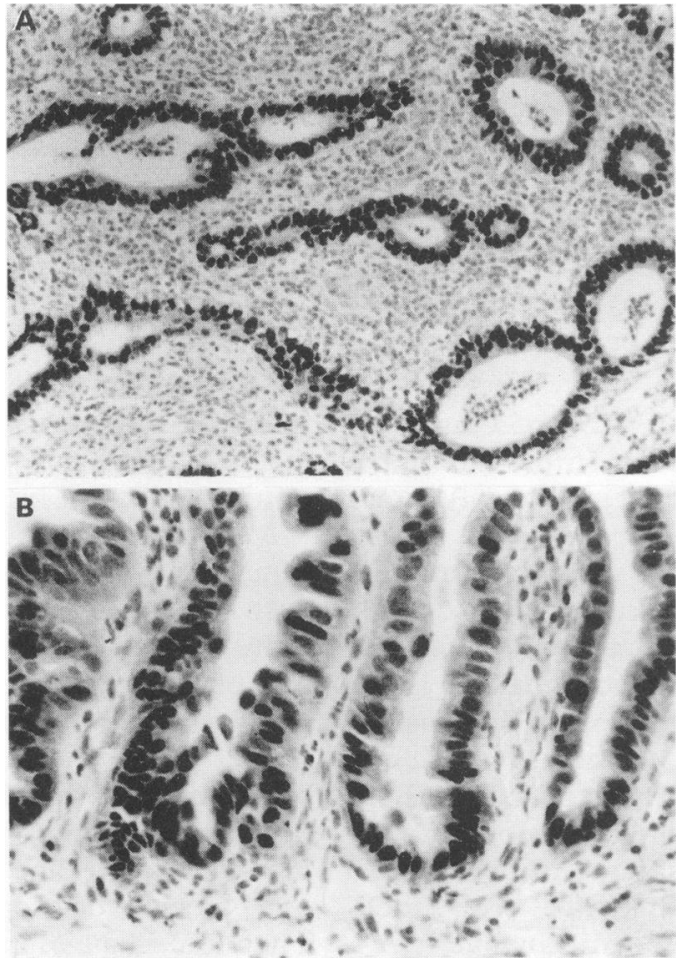

Figure 1: Intense nuclear staining for $p 53$ protein in cholangiocarcinoma tissue. (A): Well differentiated adenocarcinoma with extensive inflammatory infiltrate in the stroma. (B): Malignant glandular epithelium lying in the lumen of a large intrahepatic duct.

with $1 \%$ hydrogen peroxide in methanol for 15 minutes. The sections were transferred into $0.01 \mathrm{M}$ citrate buffer ( $\mathrm{pH} 6.0$ ) and microwaved for 15-20 minutes at maximum power using Proline microwave oven (Proline Power Wave 700) rated at $700 \mathrm{~W} .{ }^{11} 12$ In preliminary experiments these conditions have been optimised and we have shown that microwave pretreatment is an essential step for adequate detection of $\mathrm{p} 53$ protein in formalin fixed liver specimens. The sections were subsequently incubated with TRIS buffered saline (TBS, $0.05 \mathrm{M}$ TRIS-HCL and $0.15 \mathrm{M}$ sodium chloride, $\mathrm{pH} 7 \cdot 4$ ) containing $10 \%$ normal serum from the species in which the secondary, biotinylated antibody was raised. p53 Protein was detected with a monoclonal antibody to p53 protein D01 (Cambridge Bioscience, UK) diluted $1: 100$ in $\mathrm{TBS}$, for 60 minutes at $37^{\circ} \mathrm{C}$. The sections were washed and then incubated for 30 minutes with a biotinylated rabbit antimouse antibody (DAKO Ltd, High Wycombe, UK) diluted 1:400 in TBS, followed by Streptavidin ABC (DAKO Ltd) diluted in TBS 1:200 for 30 minutes. The peroxidase substrate was $3^{\prime}, 3$-diaminobenzine-tetrahydrochloride $(0.5 \mathrm{mg} / \mathrm{ml})$ in TBS plus $0.01 \%$ $\mathrm{H}_{2} \mathrm{O}_{2}$ and was applied to the tissue for five minutes. The sections were then counterstained with haematoxylin, dehydrated, and mounted in distrene-tricresyl phosphatexilene. Nuclear staining for p53 protein was defined as intense if a positive reaction was present in more than $80 \%$ of the nuclei and weak if less than $20 \%$ were positive. The immunostaining was assessed by two independent observers (PMR and BP). As positive controls for immunodetection of mutant p53 protein we used two hepatoma cell lines (PLC/PRF/5 and HUH-7), which have different mutations in the $\mathrm{p} 53$ gene and are known to produce mutant p53 proteins. ${ }^{13}$ Both cell lines were cultured under standard conditions, the cells were trypsinised, washed, and the cell pellets were fixed in buffered formalin and embedded in paraffin wax. The positive staining with the monoclonal D01 antibody was also compared with a polyclonal rabbit antibody to p53 protein (kindly donated by Dr H Zentgraff, DKFZ, Heidelberg, Germany), diluted 1:500, and detected with a biotinylated goat antirabbit antibody and Streptavidin ABC (DAKO Ltd). The negative controls included replacement of the primary antibody to $\mathrm{p} 53$ with buffer only or a monoclonal antibody with different specificity, as well as immunostaining of normal liver tissue with anti-p53.

\section{Results}

Accumulation of p53 protein was shown as dense nuclear staining in the neoplastic tissue of 11 of 14 cholangiocarcinoma samples $(78 \cdot 5 \%)$. In seven cases, the staining was intense and present in more than $80 \%$ of the cells (Fig 1), while in the remaining four cases it was seen in some $20 \%$ of the nuclei. The proportion of cells with overexpression of $\mathrm{p} 53$ protein did not correlate with serum biochemistry and the serum tumour markers or the histological classification of cholangiocarcinoma (Table).

Characteristics of patients with cholangiocarcinoma and p53 protein expression in the neoplastic biliary epithelium

\begin{tabular}{|c|c|c|c|c|c|c|c|}
\hline \multirow[b]{2}{*}{ No } & \multicolumn{5}{|c|}{ Biochemistry and tumour markers } & \multicolumn{2}{|l|}{ Neoplastic biliary epithelium } \\
\hline & $\begin{array}{l}\text { Bilirubin } \\
(\mu \mathrm{moln}) \\
(\mathrm{NR}=3-20)\end{array}$ & $\begin{array}{l}\text { Alkaline phosphatase } \\
(I U /) \\
(N R=30-120)\end{array}$ & $\begin{array}{l}\text { Albumin } \\
(g /)) \\
(N R=35-50)\end{array}$ & $\begin{array}{l}\mathrm{Cea} \\
(\mathrm{ng} / \mathrm{ml}) \\
(\mathrm{NR}=<5)\end{array}$ & $\begin{array}{l}\text { Ca } 19-9 \\
(U / m l) \\
(N R=<200)^{\star}\end{array}$ & $\begin{array}{l}\text { Histological type } \\
\text { (adenoca) }\end{array}$ & $\begin{array}{l}\text { p53 Nuclear } \\
\text { staining }\end{array}$ \\
\hline $\begin{array}{r}1 \\
2 \\
3 \\
4 \\
5 \\
6 \\
7 \\
8 \\
9 \\
10 \\
11 \\
12 \\
13 \\
14\end{array}$ & $\begin{array}{l}339 \\
328 \\
206 \\
306 \\
150 \\
201 \\
324 \\
358 \\
346 \\
\text { NA } \\
911 \\
\text { NA } \\
135 \\
\text { NA }\end{array}$ & $\begin{array}{r}1849 \\
1925 \\
1083 \\
786 \\
1084 \\
1587 \\
1155 \\
998 \\
1932 \\
\text { NA } \\
641 \\
\text { NA } \\
866 \\
\text { NA }\end{array}$ & $\begin{array}{l}19 \\
37 \\
28 \\
33 \\
44 \\
37 \\
35 \\
32 \\
34 \\
\text { NA } \\
28 \\
\text { NA } \\
22 \\
\text { NA }\end{array}$ & $\begin{array}{c}10 \\
56 \\
9 \\
1 \\
3 \\
1 \\
16 \\
61 \\
2 \\
\text { NA } \\
1 \\
\text { NA } \\
1 \\
\text { NA }\end{array}$ & $\begin{array}{c}81362 \\
20219 \\
334 \\
254 \\
26 \\
346 \\
24 \\
51 \\
44 \\
\text { NA } \\
126 \\
\text { NA } \\
3081 \\
\text { NA }\end{array}$ & $\begin{array}{l}\text { Muco-secreting } \\
\text { Papillary } \\
\text { Muco-secreting } \\
\text { Muco-secreting } \\
\text { Tubular } \\
\text { Muco-secreting } \\
\text { Papillary-muco secreting } \\
\text { Tubular } \\
\text { Papillary-muco secreting } \\
\text { Muco-secreting } \\
\text { Tubular } \\
\text { Tubulo-papillary } \\
\text { Muco-secreting } \\
\text { Muco-secreting }\end{array}$ & $\begin{array}{l}>80 \%+\text { ve } \\
>80 \%+\text { +ve } \\
<50 \% \text { +ve } \\
- \text { ve } \\
100 \%+\text { ve } \\
<10 \%+\text { ve } \\
>80 \%+\text { ve } \\
<10 \%+\text { ve } \\
\text {-ve } \\
\text {-ve } \\
>80 \%+\text { ve } \\
10 \%+\text { ve } \\
>80 \%+\text { ve } \\
>80 \%+\text { ve }\end{array}$ \\
\hline
\end{tabular}

$\mathrm{NA}=$ data not available; $\mathrm{NR}=$ normal range. $\mathrm{Cea}=$ carcinoembryonic antigen, $\mathrm{Ca}$ 19-9=carbohydrate antigen 19-9. 


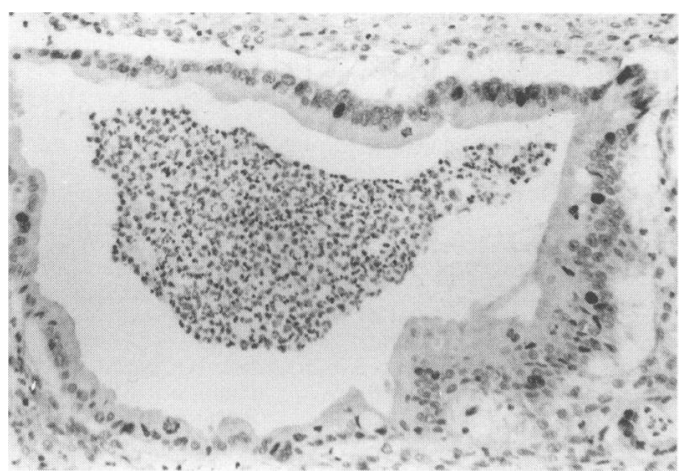

Figure 2: Dysplastic and focally malignant epithelium mimicking a septal bile duct with pus in the lumen.

In five of 10 patients with PSC and cholangiocarcinoma, screening of large tissue blocks including perihilar tissue showed, away from the main tumour area, small islands of biliary epithelium whose nuclei stained strongly for p53 protein (Fig 2). These glandular elements were not noticed on the haematoxylin preparation because of their high degree of differentiation, which mimicked bile duct branches or islands of accessory seromucinous glands. In retrospect they appeared more consistent with highly differentiated tumour glands within thin walled lymphatic channels or distant foci of well differentiated, tubular adenocarcinoma, or both. In addition, minute nests of carcinoma cells were similarly highlighted within perineural tissue and lymphatics by nuclear p53 staining (Fig 3). In a single case a sample of bile duct epithelium obtained by ERCP and diagnosed as dysplastic showed a focus of p53 nuclear staining; this potentially neoplastic area was not recognised as such by conventional histology.

In the 15 patients with PSC without cholangiocarcinoma there was no nuclear staining for p53 protein in the liver tissue.

\section{Discussion}

This study shows that $\mathrm{p} 53$ protein is overexpressed in a high proportion $(78.5 \%)$ of cholangiocarcinoma developed in patients with PSC. This tumour usually originates above the junction between the cystic and the hepatic duct, and often spreads along the nerves and the nearby vascular structures invading the liver parenchyma. ${ }^{14}$ This mode of metastatic spread is further highlighted by

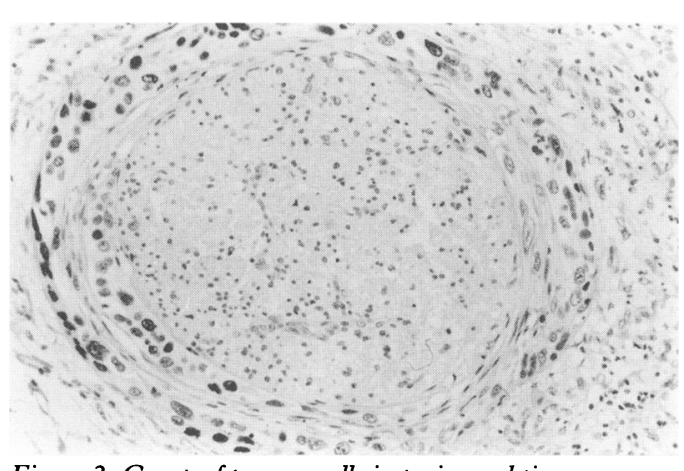

Figure 3: Group of tumour cells in perineural tissue highlighted by $p 53$ staining. p53 protein staining, which allowed the recognition of minute tumour deposits.

The detection of mutant p53 protein has important implications for the clinical practice. ${ }^{1516}$ It has recently been shown that p53 dependent apoptosis modulates the cytotoxic effects of ionising radiation and chemotherapy agents, ${ }^{17}$ raising the possibility that the p53 gene participates in the mechanism of multidrug resistance. ${ }^{18}$ In patients with solid tumours both poor prognosis and failure of chemotherapy may be associated with the abnormalities of $\mathrm{p} 53$ mutations. ${ }^{15}$ The finding of a high prevalence of mutant p53 accumulation in cholangiocarcinoma may be linked with the rapid progression of this tumour and its poor response to different therapeutic approaches.

In a recent series of cholangiocarcinoma samples from Japan, overexpression of the p53 protein was detected in $22 \%$ of surgical tumour specimens. ${ }^{19}$ In that study the underlying state of the liver is not described. In our series, the cholangiocarcinoma arose on the background of PSC, and the prevalence of p53 staining in the neoplastic tissue was very high when compared with that obtained by Terada et al. ${ }^{19}$ In our study there was no convincing evidence that normal or inflamed, but nonneoplastic biliary epithelium outside the tumour bulk stained for p53 protein and all 15 cases with longstanding PSC without associated cholangiocarcinoma were negative in that respect. This would suggest that the accumulation of p53 is a late stage in the development of the malignant process.

A very close correlation between immunohistochemical overexpression of p53 protein and mutations in the p53 gene has been established, ${ }^{20}$ and positive tissue staining for $\mathrm{p} 53$ protein has been proposed as a marker of malignancies. ${ }^{1621}$ Detection of mutant p53 protein in tissue biopsy material could be of value in the follow up of patients with PSC. In these patients it may be very difficult to distinguish between benign and malignant bile duct strictures. Immunohistochemical staining for intracellular components such as carcinoembryonic antigen ${ }^{22}$ have been used to identify cells with cholangiocarcinoma phenotype. Our finding of positive staining for $\mathrm{p} 53$ protein in malignant cells outside the main tumour mass suggests that immunohistochemical detection of p53 protein could represent an additional criterion for establishing a diagnosis of cholangiocarcinoma in PSC.

1 Levine AJ, Momand J, Finlay CA. The p53 tumour suppressor gene. Nature 1991; 351: 453-6.

2 Lane DP. A death in the life of p53. Nature 1993; 362: 786-7.

3 Gammon JV, Greaves R, Iggo R, Lane DP. Activating mutations in $\mathrm{p} 53$ produce a common conformational effect: a monoclonal antibody specific for the mutant form. $E M B O$ f 1990; 9: 1595-602

4 Hsu IC, Metcalf RA, Sun T, Welsh JA, Wang NJ, Harris CC. Mutational hotspot in the p53 gene in human hepatocellular carcinomas. Nature 1991; 350: 427-8.

5 Bressac B, Kew M, Wands J, Ozturk M. Selective G to T mutations of p53 gene in hepatocellular carcinoma from southern Africa. Nature 1991; 350: 429-31.

$6 \mathrm{Kar}$ S, Jaffe R, Carr BI. Mutations at codon of p53 gene in human hepatoblastoma. Hepatology 1993; 18: 566-9.

7 Porter PL, Gown AM, Kramp SG, Coltrera MD. Widespread p53 overexpression in human malignant tumours. Am F Pathol 1992; 140: 145-53. 
8 Fearon ER, Vogelstein B. A genetic model for colorectal tumorigenesis. Cell 1990; 61: 759-67.

9 Rosen CB, Nagorney DM, Wiesner RH, Coffey RJ, Larusso NF. Cholangiocarcinoma complicating primary sclerosing cholangitis. Ann Surg 1991; 213: 21-5.

10 Ramage JK, Donaghy A, Farrant M, Iorns R, Williams R. Serum tumour markers for the diagnosis of cholangiocarcinoma in primary sclerosing cholangitis. Gastroenterology 1995; 108: 865-9.

11 McKee PH, Hobbs C, Hall PA. Antigen retrieval by microwave irradiation lowers immunohistological detection thresholds. Histopathology 1993; 23: 377-9.

12 Shi SR, Key ME, Lalra KL. Antigen retrival in formalinfixed, paraffin embedded tissues: an enhanced method for immunohistochemical staining based on microwave over heating of tissue sections. F Histochem Cytochem 1991; 39: 741 .

13 Bressac B, Gavin KM, Liang TJ, Isselbacher KJ, Wands JR, Ozturk M. Abnormal structure and expression of $\mathrm{p} 53$ gene in human HCC. Proc Natl Acad Sci USA 1990; 87: 1973-7. 14 Vauthhey JN, Blumgart LH. Recent advances in the management of cholangiocarcinoma. Semin Liv Dis 1994; 14: 109-15.

15 Kinzler KW, Volgstein B. Clinical implications of basic research. Cancer therapy meets p53. N Engl f Med 1994 331: $49-50$.
16 Harris CC, Hollstein M. Clinical implications of the p53 tumour suppressor gene. $N$ Engl $f$ Med 1993; 329: 1318-27.

17 Lowe SW, Ruley HE, Jacks T, Housman DE. p53-dependent apoptosis modulates the cytotoxicity of anticancer agents. Cell 1993; 74: 957-67.

18 Chin KV, Ueda K, Pastan I, Gottesman MM. Modulation of activity of the promoter of the human MDR1 gene by Ras and p53. Science 1992; 255: 459-62.

19 Terada T, Shimizu K, Izumi R, Nakanuma Y. p53 expression in formalin-fixed, paraffin embedded archival specimens of intrahepatic cholangiocarcinoma: retrieval of p53 antigenicity by microwave oven heating of tissue sections. Mod Pathol 1994; 7: 249-52.

20 Baast IO, Mulder JWR, Offerhaust GJA, Vogelstain B, Hamilton SR. An evaluation of six antibodies for immunohistochemistry of mutant $\mathrm{p} 53$ gene product in archival colorectal neoplasm. I Pathol 1994; 172: in $\operatorname{archi}$

21 Hall PA, Lane DP. p53 in tumour pathology: Can we trust immunohistochemistry? - Revisited. F Pathol 1994; 172: $1-4$

22 Nakajima T, Kondo Y. Well differentiated cholangiocarcinoma: diagnostic significance of morphologic and immunohistochemical parameters. Am f Surg Pathol 1989; 13: 569-73. 